UDC: $341.81(47):(=163.41: 497.115) “ 18 “$

Славиша Недељковић

Универзитет у Нишу

Филозофски факултет

Департман за историју

ned.slavisa@gmail.com
Оригиналан научни рад

примљено: 24. април 2013

прихваћено: 1. октобар 2013

\title{
ИВАН СТЕПАНОВИЧ ЈАСТРЕБОВ, ПРИЈАТЕЉ И ЗАШТИТНИК СРПСКОГ НАРОДА НА КОСОВУ И МЕТОХИЈИ*
}

Сажетак: У раду је реч о службовању руског конзула Ивана Степановича Јастребова у Призрену. Убрзо после закључења Париског мировног конгреса, Косово и Метохија ушли су у поље интересовања појединих великих сила, које су деловањем на ову турску провинцију желеле да појачају свој политички и економски утицај на Балкану. Од свих руских конзула који су службовали у Призрену, својим радом у заштити и пружању помоћи српском народу на Косову и Метохији нарочито се истицао Иван Јастребов. Захваљујући великом угледу који је имао код турских власти, Јастребов је са успехом штитио српски народ од арбанашкотурских зулума. Радио је на јачању просветног и духовног живота српског народа у Старој Србији. Уживао је велико поштовање Срба на Косову и Метохији који су ценили и уважавали његову човечност, храброст и племенитост.

Кључне речи: Косово, Метохија, српски народ, Русија, конзул, Иван Степанович Јастребов, Турска, заштита, Арбанаси.

Период од Париског до Берлинског конгреса обележио је историју Европе многобројним кризама и променама у међународним политичким односима. Истовремено, то је период у коме су се јавили снажни национално-политички покрети међу појединим европским народима. Ови покрети су имали јак утицај на ослободилачке идеје које су се јавиле на Балкану а нарочито на националноослободилачке тежње кнежевине Србије. Њен национално-ослободилачки рад који је садржавао у себи како политичке тако и просветно-културне аспекте, био је усмерен на припремање балканског устанка против Турског царства и на ослобађање поробљених сународника. У зависности од општих европских и балканских прилика, као и прилика у самој Србији, приоритет је даван политичкој или пропагандној делатности. Својим национално-политичким радом, Србија је постала главни ослонац у који су биле упрте очи и полагана сва нада српског народа

\footnotetext{
* Рад је настао као резултат истраживања на пројекту Српска нација -интегративни и дезинтегративни процеси (ев. бр. 177014) Министарства просвете, науке и технолошког развоја Републике Србије.
} 
који се још увек налазио под турском влашћу. ${ }^{1}$

После завршетка Кримског рата, Србија је по одлукама Париског мировног уговора дошла под гаранцију европских сила. Европске државе гарантовале су Србији њен полунезависан статус према Турској. Србија је и даље остала вазална кнежевина са турским војним посадама у Београду и у осталим градовима у Србији. ${ }^{2}$ Вазални однос Србије према Порти, као и заинтересованост великих европских сила за очување одредби Париског уговора, стварали су велике проблеме Србији у спровођењу њеног програма усмереног на ослобођење српског народа у Турској. Свему овоме треба додати и велику несразмеру у односу снага између Србије и Турског царства. Средином 19. века, Турско царство је још увек било једно од највећих држава на свету. Турска држава се простирала на три континента и по величини територије заузимала је шесто место, а по броју становника (28.000.000) осмо место на свету. ${ }^{3}$ Једну овако велику државу, као што је била Турска, било је могуће поразити једино стварањем великог балканског савеза.

Неколико година после завршетка Париског конгреса у Србији је дошло до великих политичких промена. Одржана је Светоандрејска скупштина која је збацила са власти кнеза Александра Карађорђевића, а на српски престо вратила кнеза Милоша Обреновића. Повратак Милоша Обреновића на власт у Србији потврдила је и Висока порта својим ферманом од 3. јануара 1859. године. ${ }^{4}$ Повратак династије Обреновић, коју су подржавали Русија и Француска, донео је нови курс у српској спољној политици. Пред великим европским силама и Турском, поново је било постављено српско национално питање чија ће реализација у даљим дешавањима на Балкану бити један од кључних проблема Источног питања.

Убрзо после закључења Париског мировног уговора 1856. године, област Старе Србије ушла је у поље интересовања појединих великих сила, које су својим деловањем на ову турску провинцију желеле да појачају свој политички и економски утицај на Балкану. После завршетка Кримског рата, положај Француске као главне силе антируске коалиције, нагло је ојачао. Њен утицај се нарочито осетио у оним областима Албаније где су живела католичка племена Малисора и Миридита. ${ }^{5}$ Француски конзул у Скадру Исаинт Екар желео је да Француска има доминантан утицај на све Арбанасе. Антисловенски и антиправославно оријентисан Екар вршио је живу пропаганду међу католичким Арбанасима и подстицао их је на исељавање у српске области на Косову и Метохији. То је довело до тога да су се у Пећкој нахији већ неколико година после Париског мира појавиле разбојничке чете састављење

\footnotetext{
${ }^{1}$ Архив Косова и Метохије (даље: АКМ), Фонд Јована Јовановића Пижона (даље : ЈJП), XXVIII/K, 10695, 80-3-650, 1897, реферат Свете Симића о дипломатској интервенцији српске владе ради остварења националних циљева у Старој Србији и Македонији - министру Владану Ђорђевићу.

${ }^{2}$ Владимир Ђоровић, Историја Срба, Београд 1993, 617.

${ }^{3}$ Славенко Терзић, Србија и Грчка (1856-1903),борба за Балкан, Београд 1992, 50-51; Јован Хаџи Васиљевић, Српски народ и турске реформе, Братство 15, Београд 1921, 123-125.

${ }^{4}$ Слободан Јовановић, Друга влада Милоша и Михаила, Београд 1933, 1.

${ }^{5}$ Владимир Стојанчевић, Обновљена српска држава и Арбанаси 1804-1876. године, Зборник радова, Србија и Албанци у XIX почетком XX века (CAHУ, научни скупови, књига LIII, одељење историјских наука, књига 15), Београд 1990, 23.
} 
искључиво од католика. Знајући колики је значај манастир Дечане имао за српско становништво у Старој Србији, конзул Екар је вршио снажан притисак на ову стару српску задужбину не би ли је приморао на унију. Он је најпре сиромашном братству манастира Дечане понудио значајну финансијску помоћ као и заштиту од арбанашких напада, а када то није донело оно што је очекивао, онда је он ангажовао и турске власти не би ли се манастир Дечане силом превео у унију. ${ }^{6}$ Француски утицај на подручију Скадарског и Призренског вилајета трајао је до француског слома у рату против Пруске (1870/1871), а онда је нестао препустивши овај простор другој католичкој држави, Аустро-Угарској.

Већ од 1856. године, на подручју Косова и Метохије се све јаче осећао утицај Хабзбуршке монархије. Још у то време, у Бечу су се могле чути идеје да Аустрија мора да уђе на Балкан како би завршила дело принца Еугена Савојског, као и то да она у споразуму са Русијом треба да припоји себи: Босну, Србију, Албанију и западну Македонију. ${ }^{7}$ Да би осигурала своје политичко и економско ширење у правцу Солуна, Аустрија је појачала свој политичко-пропагандни рад на Косову, Метохији и у северној Албанији. Снажан политички утицај захтевао је постојање дипломатске мреже, па је средином 19. века Аустрија отворила свој конзулат у Скадру а 1856. године и конзулат у Призрену. ${ }^{8}$ Први аустријски конзул у Призрену био је доктор медицине Петелену. ${ }^{9}$ Аустријски конзулат у Призрену је по плановима бечке дипломатије требало да постане снажан центар одакле би се ширила политичка, културна и верска пропаганда кроз читаву Стару Србију. Овај конзулат је истовремено имао задатак и да неутралише утицај царске Русије, као и деловање Србије и Црне Горе. Аустро-Угарска је преко своје пропаганде настојала да створи што већу међунационалну и верску нетрпељивост међу становништвом Старе Србије, а нарочито је подстицала мржњу Арбанаса према српском становништву. Она је у своје редове успела да укључи многе католичке свештенике из Метохије, као и један број муслиманских ага и бегова, чију су наклоност уз помоћ злата и скупоцених поклона куповали аустријски конзули у Скадру и Призрену. Благонаклони према Арбанасима, аустријски конзули у Турској су према православном српском становиштву имали потпуно другачији став. Ако се ко од косовско-метохијских Срба, што је иначе било веома ретко, притиснут муком, јављао аустријском конзулату и тражио заштиту од арбанашких зулума, одговарано му је да конзулат нема право да се меша у унутрашња питања Турске, или се једноставно прелазило преко ових жалби као да нису ни постојале. Кад год су руски конзули због службених или приватних разлога одсуствовали из Призрена, тамошњи аустријски конзулат је то користио и преко Арбанаса појачавао притисак на српско становништво у Призрену. ${ }^{10}$

\footnotetext{
${ }^{6}$ Владимир Стојанчевић, Србија и Арбанси 1804-1912, Нови Сад 1994, 274.

${ }^{7}$ Славиша Недељковић, Србија и Косово и Метохија (1856-1897), културно просветни и национални рад, Ниш 2012, 162.

${ }^{8}$ Владимир Бован, Јастребов у Призрену, Приштина 1983, 56.

${ }^{9}$ Петар Костић, Просветно-културни живот православних Срба у Призрену и његовој околини у ХІХ и почетком ХХ века (са успоменама писиа), Скопље 1933,165.

${ }^{10}$ С. Недељковић, Нав. д., 163.
} 
Једна од великих европских сила чији се утицај осећао у централним деловима Старе Србије била је Русија. Четрдесетих и педесетих година 19. века, руски утицај је углавном долазио преко црквених књига и новчане помоћи коју су поједини манастири и школе добијали од руске владе. Знајући да српски народ у Турској живи у веома тешким условима, руска влада је повремено излазила у сусрет молбама у којима су српске црквено-школске општине тражиле помоћ. Захваљујући новчаној помоћи из Русије, 1852. године обновљен је манастир Бања, који се налазио у развалинама од 1580. године, када су га порушили Турци. Уз манастир, била је подигнута и школа, која је имала веома значајну улогу у описмењавању српске деце у Метохији. ${ }^{11}$ Да би пратила аустријски и француски утицај, који се од 1853. године, све јаче осећао у севереној Албанији и Старој Србији, Русија је 1856. године основала свој конзулат у Скадру. ${ }^{12}$ Педесетих и шездесетих година 19. века, Русија је са великом пажњом пратила развој политичких прилика у Румелији. Преко својих агената који су деловали на терену, Русија је остваривала контакте са појединим арбанашким феудалцима и у сарадњи са кнежевином Србијом радила на подизању великог устанка балканских хришћана против Турске. ${ }^{13}$ Од 1860. до 1867. године, односи између Русије и Србије били су веома добри. Русија је помагала рад на Балкану и упућивала је балканске државе и народе на Београд као политички центар, око којег треба да се окупе у борби за коначно рушење турске власти. О томе колико су тадашњи политички односи између Србије и Русије били добри, најбоље сведочи податак да су се у руским конзулатима чувале шифре агената српске владе, који су преко руске службене конзуларне поште слали поверљиве извештаје из Турске за Београд. ${ }^{14}$ После 1867. године, српско-руски односи нису више били тако добри, али без обзира на то у какавим је односима била са Београдом, Русија је увек настојала да преко свог посланства и конзулата у Турској помаже српском народу у Отоманској царевини. Срби из Турске су у Русији гледали великог заштитника православне вере и моћног противника њихових муслиманских господара.

Прва иницијатива за отварање руског конзулата у Призрену потекла је од учитеља Николе Мусулина. ${ }^{15}$ Увидевши колико је добрих и корисних ствари за

\footnotetext{
${ }^{11}$ Архив Србије (даље : АС), Министарство просвете и црквених дела, Просветно одељење (даље : МПсП), 1869, ф III, p 1753, № 4381, Београд 23. септембар 1869.

${ }^{12}$ В. Бован, Нав. дело, $17-18$.

${ }^{13}$ Србија и ослободилачки покрети на Балкану од Париског мира до Берилнског конгреса (1856-1878), къига I (1856-1866) (прир. Василије Крестић и Радош Љушић), Београд 1983, 526-527.

${ }^{14}$ Ђоко Слијепчевић, Српско-арбанашки односи кроз векове са особеним освртом на новије време, Хилместир, 1983, 171.

${ }^{15}$ Никола Мусулин Гомирац (1827-1903), учитељ, национални радник, писац. Рођен је у Гомирју, завршио је богословију у Сремским Карловцима и као учитељ радио је у Загребу (1851). Од 1853. до 1856. године, Мусулин је као учитељ радио у српској школи у Скадру, где је за кратко време успео да „запуштени српски народ који је већ био сасвим арнаутски језик и обичаје примио, врати на пут српске народности“. Мусулин је у Скадру остао до 1856. године, када је на позив познатог трговца Димиша МладеновићаМишетовића оставио Скадар и отишао у Призрен. Мусулин је као учитељ био веома активан и брзо је стекао велики углед код призренских Срба. Као свршени карловачки богослов, Мусулин је увео српско певање у цркви. Захваљујући њему, српске школе у Метохији добиле су крајем 1856. године већу количину школских књига. Поред просветног рада Мусулин се активно бавио и национално-политичким радом. Због ширења српске националне идеје, он је још у Скадру дошао у сукоб са тамошњим
} 
српску општину у Скадру учинио тамошњи руски конзулат, Мусулин је желео да се у Призрену, великом српском трговачком и занатском центру, отвори руски конзулат. Разлози за то били су очигледни. Доласком руског конзула у Призрен, метохијски Срби добили би моћног заштитника који би их са успехом бранио од корумпираних турских власти и фанатизованих Арбанаса. Ову Мусулинову идеју прихватио је знаменити призренски Србин и задужбинар Сима Андрејевић Игуманов. ${ }^{16}$ Он је приликом свог првог доласка у Призрен (1864. године), најпре код српског живља у Призренском вилајету, а потом и код руског посланства у Цариграду спровео широку акцију како би се у Призрену што пре основао руски конзулат. Игуманова упорност се исплатила, тако да је 1. јула 1866 . године руски конзулат у Призрену отпочео са радом. ${ }^{17}$ Први руски конзул у Призрену био је Евгеније Тимајев. Он је у Призрену остао до 1870. године, а српски живаљ у Метохији га је упамтио као великог заштитника српског народа и православних цркава и манастира на Косову и Метохији. ${ }^{18}$ Његов покровитељски посао наставио је Иван Степанович Јастребов. Он је конзуловао у Призрену у два маха: од 1870. до 1874. године и од 1879. до 1888.

католичким свештеницима. По свом доласку у Призрен, дошао је у сукоб са митрополитом Мелентијем који није волео школоване учитеље а засигурно му је засметао и Мусулинов политички став. Мелентије је јавно осућивао Мусулинов рад, забрањивао је Призренцима да шаљу децу у школу а када ни то није било довољно, од призенског паше је захтевао да Мусулина протера из Турске. На Мелентијеву препоруку, у све ово се умешала и Цариградска патријаршија, која је Мусулина прогласила за јеретика, те је на њега бацила анатему која је била прочитана пред народом у цркви. Мусулин је 1859. године отишао у Србију, где је (ако се изузме период од 1861/1862, када је боравио у Црној Гори) остао до своје смрти. Пензионисан је 1874. године. АС, Митрополија Београдска (даље: МБ), 1857, № 8, Никола Мусулин српском митрополиту у Београду, Призрен, 14. децембар 1856; АС, лични фонд Љубомира Ковачевића (даље: ЉК), бр. 357, Нови прилози за биографију Николе Мусулина; Јагош К. Ђилас, Српске школе на Косову од 1856. до 1912. године, Приштина 1969, 70-74; Светозар Чановић, Српске школе на Косову и Метохији, Приштина 1976, 152-176.

${ }^{16}$ Сима Андрејевић Игуманов (1804-1882), задужбинар и народни добротвор. Рођен је у Призрену у познатој трговачкој породици. Сима је део младости провео у манастиру Св. Марка код Призрена, где је научио да чита и пише. Као трговац боравио је у Призрену, Алексинцу, Београду, Битољу, Цариграду, Кијеву и Одеси. Од 1855. почиње значајније да помаже српске цркве у Метохији, да би после његовог преласка у Кијев његова помоћ била још већа и обилнија. После тридесет година боравка ван Призрена, Сима се 1864. године тамо вратио. Он се у свом родном граду није дуго задржао. Пошто је обишао и даровао оближње српске манастире Сима се вратио у Русију у којој је остао до 1869. године. Те исте године Сима се вратио у Призрен и почео да врши припреме за отварање богословије. О томе са колико је патриотизма Игуманов помагао српске школе и цркве у Метохији најбоље сведочи податак да је у ту сврху у периоду од 1862. до 1871. године Сима Игуманов потрошио више од 10.000 цесарских дуката. Године 1880 , Сима Игуманов је саставио тестамент у коме је целу своју имовину, процењену на 6.300 .000 динара, завештао за издржавање Призренске богославије. Како ова средства нису била довољна, Сима је захтевао да се цео приход од имања може трошити тек двадесет година после његове смрти. Због тога је новац за издржавање Призренске богословије давала српска влада, док је турским властима било објашњено да новац за издржавање школе потиче из оставштине која се даје преко Фонда Симе Игуманова. Александра Марковић Новаков, Православна српска богословија у Призрену (1871-1890), Ниш 2011, 183-186; Споменииа педесетогодишьице призренске богословско-учитељьке школе 1871-1921, Београд 1925, 7-24; Михаило Војводић, Стојан Новаковић и Владимир Карић, Београд 2003, 214; П. Костић, Нав. дело, 3-62.

${ }^{17}$ Петар Костић, Европски конзули у Призрену, Јужни преглед 5, Скопље 1928, 208.

${ }^{18}$ В. Бован, Нав. дело, 57. 
године. У периоду од 1874. до маја 1875. године на челу руског конзулата у Призрену налазио се конзул Лисевич. Од маја 1875. па до 1879. године руски конзулат у Призрену био је затворен. ${ }^{19}$ Отварање руског конзулата у Призрену било је од великог значаја за српски народ на Косову и Метохији, јер је то била једина установа од које су тамошњи Срби могли да затраже помоћ. Руски конзулат у Призрену често је код локалних турских власти интервенисао у корист Срба а када је за то било потребе, и код Високе порте преко свог посланства у Цариграду. Отварање руског конзулата у Призрену било је значајно и за просветно-културни живот на Косову и Метохији. Преко руског конзулата у Призрену, српска влада је често слала књиге и новчану помоћ за српске школе и манастире. Руски конзулат је стално снадбевао књигама библиотеку Призренске богословије тако да је она временом постала библиотека са највећим књижним фондом у Старој Србији. ${ }^{20}$ Од руских дипломата који су службовали у конзулату у Призрену највећи траг код тамошњих Срба оставио је Иван Степанович Јастребов. ${ }^{21}$ Одмах по доласку у Призрен, Јастребов је интервенисао код вилајетских власти, како би се за тамошње српско хришћанско становништво обезбедила права и сигурност које су гарантовали отомански закони. ${ }^{22}$ Поред заштите српског становништва од арбанашко-турских зулума Јастребов је веома много урадио на унапређењу културно-просветног живота Срба на Косову и Метохији. Средином 19. века, српски народ на Косову и Метохији живео је у патријархалном друштву, веран својим обичајима и православној вери. Црква и школа представљале су његове две најбитније институције у Турској. Оне су практично биле нераздвојиве, јер су школе могле да опстану само као део црквене институције. Просвећивање српског народа на Косову и Метохији било је могуће једино реорганизацијом тамошњег школског система. Српске школе у Старој Србији

\footnotetext{
${ }^{19}$ Иван Степанович Јастребов, Стара Србија, Приштина 1995, 51.

${ }^{20}$ Ј. К. Ђилас, Нав. дело, 33.

${ }^{21}$ Иван Степанович Јастребов, дипломата, етнограф (Громушка, Тамбовска губернија, Русија, 27. I 1839 Солун, 7. I 1894). Детињство је провео на Кавказу. Школовао се у Астраханском семеништу, а потом у Казанској духовној академији, коју је завршио 1864. године. Познавао је класичне језике, усавршавао се на Одељењу за изучавње источних језика при Азијском департману Министарства иностраних дела у Петрограду, где је научио турски, арапски и персијски језик. Дипломатску каријеру започео је као чиновник у руском посланству у Цариграду у рангу вежбаника (1866). Цео радни век провео је у балканским земљама. У служби је брзо напредовао, тако да је већ 1867. године постављен за тумача и секретара конзулта у Скадру а наредне 1868. године за руководиоца поменутог конзулата. Поред службовања у Скадру и Призрену једно време је био конзул и у Дубровнику. Од августа 1880 . до септембра 1881. био је конзул у Јањини. После службовања у Призрену, постављен је за генералног конзула у Солуну, што представља врхунац његове дипломатске каријере. Поред дипломатске каријере Јастребов је био и врстан научник. Објавио је велики број научних радова. Дописни члан Српског ученог друштва постао је 1876, а дописни члан Српске краљевске академије 1888. године. Био је одликован: Орденом Таковског крста III реда, Орденом Св. Саве I и II реда, Знаком Црвеног крста, Медаљом Друштва Свети Сава и Орденом Независности Црне Горе I и II реда. Сву покретну имовину завештао је Српској гимназији у Солуну. Сахрањен је на Солунском гробљу. А. Марковић Новаков, Нав. дело, 186-188; В. Бован, Нав. дело, 65-80; Ђоко Слијепчевић, Михаило, архиепископ београдски и митроплит Србије, Минхен 1980, 440-451; Милутин Тимотијевић, Иван Степанович Јастребов и Призренска богословија, Зборник радова, Иван Степанович Јастребов, Призрен 1997, 33-41; Ј. К. Ђилас, Нав. дело, 32-34.

${ }^{22}$ В. Бован, Нав. дело, 65-67.
} 
су се у то време налазиле на релативно ниском ступњу разоја. Настава која се изводила у овим школама имала је искључиво верски карактер и служила је за потребе цркве. У зависности од знања и заинтересованости учитеља, ђаци су стицали писменост и основна знања из рачунске наставе. ${ }^{23}$ Како световну наставу у овим школама више нису могли да изводе слабо образовани „учитељи“ а потребе за школованим учитељима још увек нису могле бити задовољене слањем ђака из ових крајева на школовање у Србију, пред Министарством просвете и црквених дела појавио се проблем који је могао да заустави српски културно-просветни и национални рад у Турској. Знајући да је квалификовани наставни кадар веома битан фактор у развитку школа и ширењу просвете, Јастребов је убрзо по свом доласку у Призрен српским просветним властима препоручио отварање једне посебне школе у Турској, која би школовала српске учитеље и свештенике. ${ }^{24}$ Постојање једне овакве богословско-учитељске школе имало би поред просветног и велики националнополитички значај. Таква школа представљала би праву тврђаву Српства која би се са успехом супротстављала страним пропагандама чије се деловање све више осећало на Косову и Метохији. Анализирајући овај предлог, српско Министарство просвете дошло је до закључка да се ово питање може решити на два начина. Први начин је претпостављао да се у Србији отвори посебна богословско-учитељска школа у којој би се школовала само деца из српских крајева под Турцима, а други начин је предвиђао отварање овакве школе у неком већем центру у Старој Србији. На основу анализе свих чињеница са којима је располагало, Министарство просвете се определило за другу опцију, односно отварање богословско-учитељске школе у Турској. Отварањем ове школе решио би се хронични недостатак учитељског и свештеничког кадра а истовремено би се зауставио утицај Римокатоличке цркве у Метохији који се све јаче осећао после 1856 . године. ${ }^{25}$

Управо из ових разлога српска влада је још 1866. године упутила мемоар руској влади у коме је тражила помоћ за отварање богословија у Босни, Херцеговини, Старој Србији и Албанији. Осим дипломатске помоћи која је била неопходна да би се од Цариградске патријаршије добило одобрење за рад ових школа, српска влада је од руског правитељства тражила новчану помоћ која је за три планиране богословије, у: Сарајеву, Житомислићу или Мостару и Призрену или Пећкој патријаршији, износила 4.959 рубаља. Са своје стране, српска влада се обавезала да ће овим богословским школама, уколико почну да раде, обезбедити све потребне уџбенике и наставна средства. ${ }^{26}$ Октобра 1871. године почела је са радом

\footnotetext{
${ }^{23}$ Архив Српске академије наука и уметности (даље : АСАНУ), Етнографска збирка Дене Дебељковића Е469-III-34.

${ }^{24} \mathrm{AC}$, МПс-П, 1871, ф V, р оㅡ 68, Призрен 20. април 171; АС, Министарство иностраних дела (даље: МИД), Политичко одељење (даље: ПО), 1874, Т/1, пов. № 74, Београд 1. март 1874.

25 АС, МИД, Просветно-политичко одељење (даље: ПП), 1886, ф I, p 3, Милош С. Милојевић -Министарству просвете и црквених дела, Лесковац, 30. јуни 1886; Архив Историјског института САНУ, (даље: АИИ), Лични фонд Јована Ристића (даље: ЈР), инв. бр. 12/308, сигн. ХІІ/5, Милун Новичић митрополиту Михаилу, Призрен, 30. јули 1871; Исто, инв. бр. 26/889, сигн. ХХVI/13, митрополит Михаило - Јовану Ристићу, Београд, 9. април 1871.

${ }^{26}$ АИИ, ЈР, инв. бр. 12/308, сигн. ХІІ/5, Београд, 30. август 1871.
} 
Призренска богословија, прва средња школа на српском језику у Турској. Управитељ школе био је архимандрит Сава Дечанац, а наставници Милун Новичић и Илија Ставрић. Од свог оснивања Призренска богословија се прво налазила под надзором Министарства просвете и црквених дела а потом је прешла у надлежност Политичко-просветног одељења Министарства иностраних дела Србије. У преписци коју је Призренска богословија водила са овим одељењем Министарства стајао је назив „Главно туторство Фонда Симе А. Игуманова“. За издржавање ове школе био је одрећен буџет који је од 1871. до 1881. године износио 660 дуката у злату. ${ }^{27}$ Највеће заслуге за отварање Призренске богословије свакако припадају Сими Андрејевићу Игуманову. Међутим, да у то време није деловао руски конзулат, а нарочито енергичан и способан руски конзул Иван Степанович Јастребов, велико је питање да ли би се богословија уопште отворила и опстала у тешким временима која су долазила. Користећи се привилегованим положајем који су имали, руски конзули су могли да штите Призренску богословију и њене наставнике. Преко руских конзулата ишла је сва кореспонденција коју је богословија имала са Главним туторством Фонда Симе А. Игуманова. Преко руских конзулата такође је био дистрибуиран новац за издржавање богословије, као и школске књиге и уџбеници неопходни за извођење наставе. Јастребов је дуги низ година, колико се налазио на челу овог конзулата, био прави заштитник ове школе. И онда када је по службеној дужности морао да оде из Призрена, Јастребов је водио рачуна о раду богословије и њеним наставницима. Руском конзулу Лисевичу који га је децембра 1874. године заменио у Призрену Јастребов је препоручио да води нарочиту пажњу и да се добро стара о Призренској богословији. ${ }^{28}$ И онда када је био постављен за конзула у Дубровнику, Јастребов је бринуо о раду богословије, па је преко њега у току 1877. и 1878. године био слат новац неопходан за издржавање Призренске богословије. Његовом заслугом, Словенско добротворно друштво поклонило је богословскоучитељској школи у Призрену новчану суму од хиљаду рубаља. ${ }^{29}$ И поред добрих резултата који су постигнути у првим годинама рада Призренске богословије, ова школа је већ 1873. године запала у тешку ситуацију која је претила да потпуно паралише њен рад. Разлог за то лежао је у свађама и сукобима који су избили између ректора и наставника Призренске богословије. Знајући да све то може да изазове велике проблеме, Јастребов је брзо реаговао и препоручио је српском Министарству просвете да за ректора ове школе изабере Илију Ставрића. Постављење Илије Ставрића на место управника богословије показало се као веома добар потез. Енергичан и способан, Ставрић је значајно унапредио наставни процес у Призренској богословији. Његовим радом нарочито је био задовољан конзул Јастребов, који је о њему писао да је ректор који се само пожелети може и да је у потпуности оправдао поверење које му је било указано. ${ }^{30}$ Поред ангажовања на оснивању богословије у Призрену, Јастребов је дао значајан допринос и приликом

\footnotetext{
${ }^{27}$ А. Марковић Новаков, Нав. дело, 63-70; АС, МПс-П, 1874, ф VI, р 803, № 872, Министарство просвете и црквених дела - митрополиту Михаилу, Београд, 16. фебруар 1874.

${ }^{28}$ Ђ. Слијепчевић, Нав. дело, 441-445.

${ }^{29}$ АС, МПс-П, 1878, ф ХІ, р 87, № 3572, Београд, 18. август 1878.

${ }^{30}$ А. Марковић Новаков, Нав. дело, 77-78; Ђ. Слијепчевић, Нав. дело, 444.
} 
покретања листа Призрен, првог листа на српском језику у Турској. Покретање листа Призрен било је од великог значаја за културно-просветни живот Срба на Косову и Метохији и уопште у читавој Старој Србији. Како је Призрен у то доба био седиште пространог Призренског вилајета, у њему је по наређењу Порте требало покренути издавање једног вилајетског гласника. Како призренски валија Исмаил Рамиз-паша (1868-1871) овој Портиној иницијативи није придавао већи значај, тек по доласку Сафет-паше, марта 1871. године, почеле су озбиљне припреме за издавање једног вилајетског гласила. Поред њега, значајну заслугу за покретање овог листа имао је и конзул Јастребов. Он се у договору са српском владом обавезао да ће максимално помоћи у издавању листа, док се Министарство просвете са своје стране обавезало да ће набавити штампана слова за текст на српском језику. Тако је истовремено било решено питање штампарије, као и питање издавања листа. ${ }^{31}$ Први број Призрена изашао је 2. августа 1871. године. Лист је излазио једанпут недељно и дистрибуирао се по целој европској Турској. ${ }^{32}$ Излажење овог листа изазвало је велико противљење бугарске пропаганде. Егзархистима се никако није свиђала чињеница што се овај лист радо читао не само у Призренском, већ и у Солунском, Битољском и једном делу Дунавског вилајета. Да би спречили даљи излазак овог листа, егзархисти су преко листа Дунав, који је био званичан орган Дунавског вилајета, оштро нападали српску редакцију листа Призрен. Велику помоћ у овој кампањи егзархисти су имали у нишком мутесарифу Абдурахман-паши. ${ }^{33}$ Сафетпаша је на челу Призренског вилајета остао до августа 1872. године, када га је на том месту заменио поменути Абдурахман-паша, који је одмах почео да „излива своју мржњу над штампаријом и уредницима вилајетског листа“. Он је јавно говорио да у Турској не постоје Срби, него само Бугари, и желео је да своје бугарофилске ставове пласира у листу Призрен. Томе су се храбро супротстављали Тодор Станковић и Илија Ставрић, због чега су пали у немилост Абдурахман-паше. Ову тешку и проблематичну ситуацију разрешио је конзул Јастребов, тако што је преко руске амбасаде у Цариграду, априла 1873. године, издејствовао да се Абдурахман-паша премести у Рушчук, а да се на његово место постави Хусни-паша, који је био наклоњенији Србима. $^{34}$

Прве године после завршетка Велике источне кризе биле су за српско становништво на Косову и Метохији веома тешке. Суочени најпре са деловањем Призренске лиге, а потом и са турским преким војним судовима, Срби у Турској, у првим годинама после 1878. године, нису много мислили на просвету. Изузев школа у Призренској нахији које су се налазиле под заштитом руског конзулата у Призрену, многе српске школе биле су затворене. Над оним школама које су опстале, турске

\footnotetext{
31 А. Марковић Новаков, Нав. дело, 53; Петар Митропан, Штампа Јужне Србије, Споменица двадесетпетогодишњице ослобођења Јужне Србије 1912-1937,Скопље 1937, 889.

32 Петар Костић, Просветно-културни живот православних Срба у Призрену и његовој околини у ХІХ и почетком ХХ века, 79.

${ }^{33}$ С. Недељковић, Нав. дело, 139-141; Споменииа призренске богословије, 94.

34 АС, МПс-П, 1874, ф Х, р 83, Призрен, 12. децембар 1874; Исто, ф II, p 122, Илија Ставрић Министарству просвете и црквених дела, Призрен, 6. август 1873; AKM, ПП, LV-K-1-3-1896, Хроника српске народне школе у Пећи.
} 
власти су спровеле строг надзор. У њима је било дозвољено да се деца уче писмености, али је строго била забрањена употреба српског имена. ${ }^{35}$ Руски конзулат у Призрену, обновио је свој рад 1879. године, када је за тамошњег конзула поново био изабран Јастребов. Он се врло брзо уклопио у тадашње прилике у Призрену и Старој Србији. Једноставно, наставио је тамо где је стао августа 1874. године. ${ }^{36}$ Јастребов је знао да је рад богословије много сметао турским вилајетским властима и да би оне учиниле све да нађу макар и најформалнији разлог који би им послужио да богословију затворе, ученике распусте а наставнике и управу баце у тамницу. Када су једном приликом турски полицајци упали у богословску зграду у намери да претресу школску библиотеку не би ли у њој нашли какву забрањену књигу из Србије, Јастребов је одмах отишао у богословију и на лист папира, који је закуцао на врата библиотеке, написао на турском: „У име руског цара забрањујем улаз“. Када су турски полицајци то прочитали, одустали су од намере да претресу богословску библиотеку тако да је школа захваљујући Јастребову наставила свој рад. ${ }^{37}$

Јастребов је са великом пажњом пратио рад Призренске богословије. Знајући са каквим се све проблемима наставници богословије свакодневно суочавају, Јастребов је за све време свог боравка у Призрену настојао да им са своје стране максимално помогне. Он је знао да напише писмо Министарству просвете или митрополиту Михаилу и да оштро искритикује српске просветне власти због тога што касне са слањем књига или новца богословији у Призрену. Без књига, писао је Јастребов, „као ни без алата не може се радити, а наставници, зар не треба да им се пошаљу плате? Одговорите ми што брже, како они да раде“. ${ }^{38}$ Додуше, било је и тренутака када је и сам Јастребов оптерећен многобројним проблемима једно време подржавао идеју да се богословија преуреди у основну школу а нова богословскоучитељска школа која би спремала учитеље и свештенике за Стару Србију отвори у Врању. ${ }^{39}$ Међутим без обзира на то, Јастребов је безрезервно помагао богословскоучитељску школу у Призрену и Србе у Метохији. Примера за то било је много. Српски народ на Косову и Метохији био је после завршетка Берлинског конгреса изложен систематском осветничком терору Арбанаса, који је добио организован карактер у Призренској лиги формираној уз покровитељство и подршку турских власти. Политичким деловањем Призренске лиге руководиле су арбанашке старешине које су својим положајем и вером биле дубоко везане за турску државу и њену идеологију. ${ }^{40}$ Фанатизоване и добрим делом фундаменталистички задојене, присталице Лиге су у српском становништву на Косову и Метохији видели главни узрок свих својих невоља. У свом разрачунавању са српским становништвом они

\footnotetext{
${ }^{35}$ Исто, 1888, ф XXII, р 87, Петар Костић - Министарству просвете и црквених дела, Призрен, 6. август 1884.

${ }^{36}$ Исто, 1884, ф XXIV, p 83, П бр. 1936, Министарство просвете и црквених дела - Министарству иностраних дела, Београд, 31. октобра 1884.

${ }^{37}$ В. Бован, Нав. дело, 91-100.

${ }^{38}$ Ђ. Слијепчевић, Нав. дело, 447-448.

39 А. Марковић Новаков, Нав. дело, 85-86; АИИ, ЈР, инв. бр. 16/3, сигн.ХVI/1, Матија Бан - Јовану, Ристићу, Београд, 24. март 1879.

${ }^{40}$ Михаило Војводић, Србија и балканско питање (1875-1914), Нови Сад 2001, 26-27.
} 
нису имали никаквог обзира, па су извештаји који су са Косова и Метохије пристизали у Србију, били препуни података о злочинима најгоре врсте. Оваква ситуација стварала је велике проблеме српским националним радницима. Они су морали да буду веома опрезни и да вешто прикривају свој рад, јер је и најмања грешка могла да их стаје губитка живота. Један од српских националних радника који је стално био на удару турских власти и Арбанаса био је наставник богословије, Петар Костић. Почетком априла 1880. године, један од вођа Призренске лиге, чувени качак Рамадан Заскок, пресрео је писмо Петра Костића у коме се налазио детаљан извештај о дешавањима у Метохији и о делатностима арбанашке лиге. Приликом слања извештаја Костић је, у журби, занемарио мере опреза. Уместо да извештај пошаље преко поверљивог човека Јована Денића који је имао велико искуство у овим пословима, Костић је за овај посао ангажовао неког момка из Призрена, који је по дојави српског абаџије Николе пао Арбанасима у руке. ${ }^{41}$ Чим је прочитао Костићево писмо, Рамадан је послао своје људе да Костића пронађу и убију. Сазнавши случајно за то, Костић се најпре сакрио у једном српском дућану где је сачекао ноћ, а потом се уз помоћ Јастребова пребацио у руски конзулат. Јастребов је уз помоћ енглеског конзула у Призрену, Сен Џона, успео да од турских власти идејствује гаранцију да ће Костићу живот бити поштеђен. Костић се потом предао властима које су га уз јаку пратњу ноћу преко Шар-планине и Тетова спровеле у Битољ. Јастребов је Костића свакодневно посећивао у призренском затвору и слао му је храну из руског конзулата. Јастребов је Костићу поклонио и 9 златних турских лира које су му биле од велике помоћи током његовог вишемесечног тамновања. ${ }^{42}$

Хапшење Петра Костића, управитеља богословије и значајног српског националног радника, алармирало је српску дипломатску службу. Министарство иностраних дела наложило је свом посланику на Порти да састави ,једну кратку белешку о Петру Костићу као невином човеку који лежи у турском затвору“ и да је проследи енглеском генералном конзулату у Солуну. ${ }^{43}$ Велика помоћ за ослобађање Петра Костића добијена је од руског амбасадора на Порти, као и од руских конзулата у Призрену, Битољу и Солуну, тако да је Костић после петомесечног боравка у затвору био ослобођен. ${ }^{44}$ Турске власти су ослободиле Костића под условом да напусти Турску. Он је ово прихватио и средином новембра 1880. године, са пасошем који је гласио на име Боривоје Војиновић, бродом преко Варне, отпутовао је за Београд. ${ }^{45}$

После хапшења Петра Костића, све обавезе везане за рад богословије пале су на Ђорђа Камперелића. Увидевши да недостатак стручног наставничког кадра прети да потпуно паралише рад богословије, Јастребов се обратио за помоћ српском митрополиту Михаилу, који је за новог наставника богословије одредио Илију

\footnotetext{
${ }^{41}$ АИИ, ЈР, инв. бр. 12/358, сигн. ХІІ/5, Јован Денић - Јовану Ристићу, Врање, 2. септембар 1880.

${ }^{42}$ АС, МИД, ПО, 1880, П/5-VII, Пов. Бр. 188, Врање, 22. април 1880.

${ }^{43}$ Исто, Пов. бр. 281, Јеврем Грујић - Јовану Ристићу, Цариград ,30. мај 1880.

${ }^{44}$ АИИ, Исписи, инв. бр. 66/666, сигн. ХXXIV, кут. 18, № 50, Јеврем Грујић - Јовану Ристићу, Цариград 5. август 1880.

${ }^{45}$ Исто, инв. бр. 66/675, сигн. XXXIV, кут. 18, № 58, Јеврем Грујић - Јовану Ристићу, Цариград 1. октобар 1880 .
} 
Вучетића. Родом из Старе Србије, Вучетић је завршио Београдску богословију, а потом је две године службовао као српски учитељ у Скадру. После боравка у Скадру, он је по препоруци митрополита Михаила отишао у Русију, где је најпре завршио Херсонску учитељску семинарију у трајању од три године, а затим Феодосијски учитељски институт, такође у трајању од три године. ${ }^{46}$ Како је због добијања стипендије Вучетић био у обавези да по завршетку школовања службује у Русији шест година, митрополит Михаило се обратио конзулу Јастребову, који је успео да Вучетића ослободи ове обавезе, тако да се он почетком јуна 1881. године појавио у Призрену. ${ }^{47}$ Свега неколико месеци по доласку Петра Костића у Србију, конзул Јастребов и Сима Игуманов почели су да тражи начин који би Костићу омогућио безбедан повратак у Призрен. Разлога за то било је више, а један од најбитнијих је свакако био тај што је Костић био одличан наставник и проверени национални радник. Да би се тај посао обавио како треба, Јастребов је ступио у контакт са призренским првацима Аки-ефендијом и Назиф-ефендијом и од њих затражио да од арбанашке лиге издејствују дозволу да се Петар Костић може безбедно вратити у своје родно место. Ова интервенција уродила је плодом и септембра 1881. године, Петар Костић је са турским пасошем преко Цариграда стигао у Призрен. ${ }^{48}$ Убрзо по доласку у Призрен, Костић је одлуком министра просвете Стојана Новаковића био постављен за директора Призренске богословије. Иако је као директор беспоговорно управљао радом школе, Костић је ипак био обавезан да се у свему консултује са конзулом Јастребовом и да га стално обавештава о свом раду. ${ }^{49}$

Догађаји после српско-турских ратова (1876-1878) тешко су погодили културно-просветну делатност Србије на Косову и Метохији. Турске власти су забраниле коришћење школских књига и уџбеника из Србије, тако да је сваки пренос књига био скопчан са великим ризиком. У оваквим условима, снабдевање српских школа у Турској уџбеницима из Србије било је скоро немогуће. Све је то довело до тога да је у школама било све мање књига, тако да су оне у првим годинама после завршетка Велике источне кризе биле праву драгоценост. ${ }^{50}$ Српска влада је тражила начин да овакво стање поправи, што је донекле и учињено уз помоћ руских конзулата у Скадру и Призрену. Уџбеници су били слати у Трст, одакле су преко руских конзулата стизали у Призренску богословију, која их је потом расподељивала околним српским школама. ${ }^{51}$ Иако је ово био једини сигуран начин преко којег су српске школе добијале потребне књиге, овим путем су били допремани само мањи контингенти књига и уџбеника. Због тога је децембра 1883.

\footnotetext{
${ }^{46}$ А. Марковић Новаков, Нав. дело, 203-204.

47 Архив Српске академије наука и уметности (даље: АСАНУ), Историјска збирка (даље: ИЗ), бр. 1446/562, Београд, 15. јуни 1881; АС, МПс-П, 1880, Е о 1856, београдски митрополит Михаило Министарству просвете и црквених дела, Београд, 25. октобар 1882.

${ }^{48}$ АКМ, збирка Петра Петровића (даље : ПП), LV-K1-38-1881, Петар Костић - Сими Игуманову, Призрен, 30. септембар 1881; АС, МПс-П, 1881, ф XXII, p 87, Пб, Српска богословија у Призрену - Министарству просвете и црквених дела, Призрен, 10. октобар 1881; А. Марковић Новаков, Нав. дело, 86.

${ }^{49} \mathrm{AC}$, лични фонд Стојана Новаковића, бр. 94, Београд ,10.новембар 1882.

${ }^{50}$ АИИ, JP, инв. бр. 17/36, сигн. XVII/1, архимандрит врањске епархије Сава - Јовану Ристићу, Врање, 27. август 1880.

${ }^{51}$ АC, МПс-П, 1880, ф VI, р 344, П. бр. 3669, Београд, 12. август 1880.
} 
године Јастребов предложио да се питање преношења књига и уџбеника из Србије реши на легалан начин. Он је српским просветним властима предлагао да се учине сви потребни кораци како би се од турског Министарства просвете у Цариграду добила за то дозвола. ${ }^{52}$ Српско Министарство просвете прихватило је предлог конзула Јастребова, па је у складу с тим у новембру 1884. године у Цариград био послат Петар Костић. Он је у Цариграду остао до марта 1885. године, када је од турског Министарства просвете добијена дозвола да се српски уџбеници са садржином коју је одобрила турска цензура могу штампати и растурати у Турској. ${ }^{53}$ Иван Степанович Јастребов био је велики пријатељ и заштитник српског народа на Косову и Метохији. Због тога је његова намера да напусти Призрен и своју дипломатску каријеру настави на другом месту изазвала праву пометњу у Београду. Чим је о томе био обавештен, министар Стојан Новаковић је одмах наредио српском посланству у Цариграду да интервенише код руског амбасадора Нелидова како би се спречио одлазак Јастребова из Призрена. Истовремено, преко српског посланства у Петрограду, руска влада је била замољена да не дозволи одлазак Јастребова из Призрена ,због тога што је његов рад веома драгоцен за очување српства и православља у Старој Србији“. Извештавајући министра Новаковића о разговору који је обавио са руским амбасадором, посланик Грујић је предлагао да се конзул Јастребов одликује Орденом Светог Саве другог степена са звездом, због тога „што би нам такво признавање његових заслуга дало више права на захтевање да не напушта Призрен“. 54

Избором за генералног конзула у Солуну Јастребов је достигао врхунац у својој дипломатској каријери. Одласком у Солун, није заборавио српски народ на Косову и Метохији а посебно Призренску богословију. Он је и тад, као конзул у Солуну, наставио да води рачуна о интересима Срба и помагао им је на различите начине. Када је једном приликом преко својих веза сазнао да турске власти у Призрену планирају да изврше претрес богословије, Јастребов је послао телеграм Петру Костићу у коме је писало: „Пошаљи ми остатак мојих књига“. Костић је схватио шта се крије иза ових речи и склонио је све оно што је било сумњиво из богословске библиотеке. ${ }^{55}$

Од свих руских конзула који су службовали у Призрену, својим радом у заштити и пружању помоћи српском становништву на Косову и Метохији нарочито се истицао Иван Степанович Јастребов. Био је увек наклоњен Србима, па чак и онда када се званична руска дипломатија залагала и деловала у циљу санстефанске Бугарске. Уживао је велико поштовање српског народа на Косову и Метохији који је знао да цени и уважава његову човечност, храброст и племенитост.

\footnotetext{
52 АС, МИД, ПО, 1883, Пов. бр. 32, Иван Степанович Јастребов - Туторима масе Симе А. Игуманова. Призрен, 28. децембар 1883.

${ }_{53}$ С. Недељковић, Нав. дело, 253-256.

${ }^{54}$ АС, МИД, ПО, 1884, С/1, 227, мфр. 74, Пов. бр. 15, Јеврем Грујић - Стојану Новаковићу, Цариград, 22. март 1884.

55 АС, МИД, ПП, 1889, ред 216, ф II, Пов. № 546, Српско посланство у Цариграду - Министарству иностраних дела, Цариград, 20. октобар 1888; АС, МИД, ПО, 1889, П/2, бр. 499, Београд, 10. јуни 1889.
} 


\section{Извори и литература:}

\section{Извори:}

Архив Србије:

Министарство иностраних дела, Политичко одељење.

Министарство иностраних дела, Просветно-политичко одељење.

Министарство просвете и црквених дела, Просветно одељење.

Митрополија Београдска.

Лични фонд Љубомира Ковачевића.

Лични фонд Стојана Новаковића.

Архив Српске академије наука и уметности, Етнографска збирка Дене Дебељковића.

Архив Историјског института Српске академије наука и уметности, Лични фонд Јована Ристића.

Архив Косова и Метохије:

Лични фонд Јована Јовановића Пижона.

Збирка Петра Петровића

Објављена грађа:

Србија и ослободилачки покрети на Балкану од Париског мира до Берлинског конгреса (1856-1878), књига I (1856-1866) (прир. Василије Крестић и Радош Љушић), Београд 1983.

\section{Литература:}

Бован, Владимир, Јастребов у Призрену, Приштина 1983.

Васиљевић, Хаџи Јован, Српски народ и турске реформе, Братство, бр. 15, Београд 1921.

Војводић, Михаило, Србија и балканско питање (1875-1914), Нови Сад 2001.

Војводић, Михаило, Стојан Новаковић и Владимир Карић, Београд 2003.

Ђилас, Јагош, Српске школе на Косову од 1856. до 1912. године, Приштина 1969.

Јастребов, Иван Степанович, Стара Србија, Приштина 1995.

Јовановић, Слободан, Друга влада Милоша и Михаила, Београд 1933.

Костић, Петар, Просветно-културни живот православних Срба у Призрену и његовој околини y XIX и почетком XX века (са успоменама писиа), Скопље 1933.

Костић, Петар, Европски конзули у Призрену, Јужни преглед 5, Скопље 1928.

Митропан, Петар, Штампа Јужне Србије, Споменица двадесетпетогодишњице ослобођења Јужне Србије 1912-1937, Скопље 1937.

Недељковић, Славиша, Србија и Косово и Метохија (1856-1897), културно-просветни и национални рад, Ниш 2012.

Новаков, Марковић, Александра, Православна српска богословија у Призрену (1871-1890), Ниш 2011.

Слијепчевић, Ђоко, Михаило, архиепископ београдски и митрополит Србије, Минхен 1980.

Слијепчевић, Ђоко, Српско-арбанашки односи кроз векове са особеним освртом на новије време, Хилместир 1983.

Споменииа педесетогодишњице призренске богословско-учитељске школе 1871-1921, Београд 1925.

Стојанчевић, Владимир, Срби и Арбанаси 1804-1912, Нови Сад 1994.

Стојанчевић, Владимир, Обновљена српска држава и Арбанси 1804-1876. године, Зборник радова Србија и Албанци у XIX и почетком XX века, (САНУ, научни скупови, књига 
LIII, одељење историјских наука), Београд 1990.

Терзић, Славенко, Србија и Грчка (1856-1903), борба за Балкан, Београд 1992.

Тимотијевић, Милутин, Иван Степанович Јастербов и Призренска богословија, Зборник радова „Иван Степанович Јастербов“, Призрен 1997.

Ћоровић, Владимир, Историја Срба, Београд 1993.

Чановић, Светозар, Српске школе на Косову и Метохији, Приштина 1976. 


\title{
IVAN STEPANOVIČ JASTREBOV: FRIEND AND PROTECTOR OF THE SERBIAN PEOPLE IN KOSOVO AND METOHIJA
}

\begin{abstract}
Summary
Favorable geographical position gave the Kosovo and Metohija an important role in the plans of the great powers. Shortly after the conclusion of the Paris Peace Treaty, the region of Kosovo and Metohija enters in the interest of some of great European powers, which were wanted to increase their political influence in the Balkans over this territory. In the fifties and sixties years of the 19th century, Russia with great interest followed the development of the political situation in Old Serbia, Macedonia and Albania. To successfully counter the increasingly strong Austrian propaganda, Russia's first opened a consulate in Shkoder and then in Prizren. The opening of the Russian Consulate has a great importance for the Serbian people in Kosovo and Metohija, because it was the only institution from which the local Serbs could seek for help. Of the entire Russian consul who served in Prizren, Ivan Stepanovich Jastrebov was especially active by his work and dedication. He successfully defended Serbian people of Albanian-Turkish violence, and also actively worked to strengthen of the spiritual and educational life of Serbs in the region. He visited many inaccessible Serbian villages in Metohija and collected historical, ethnological and ethnographic data. He protected orthodoxy and whenever he could, he helped Serbian churches and monasteries in Kosovo and Metohija. The establishment of the Prizren Seminary and starting of journal "Prizren", which was published in Serbian, was achieved with the help of consul Jastrebov. Everything from Serbia which was sent to Prizren Seminary went over Jastrebov, which about that school was take care as their own endowment. And when, after many years of service left Prizren, Jastrebov not forgotten Serbian people in Kosovo and Metohija, especially Prizren Seminary. He continued to take care of the interests of the local Serbs, helping them whenever the circumstances allow it. He was remembered as a great patron and friend of the Serbian people in Kosovo and Metohija.
\end{abstract}

Keywords: Kosovo, Metohija, Serbian people, Russia, consuls, Ivan Stepanovich Jastrebov, Turkey, protection, Albanians. 